\title{
Analysis of Attributes determining Consumption of Rice in Adamawa State, Nigeria
}

\author{
Hamid, M.Y.*; Gabul, P.; Moses, J.D.
}

Department of Agricultural Economics and Extension, Adamawa State University, P.M.B 25, Mubi, Adamawa State, Nigeria

*Corresponding Author

Received: 07 Nov 2020; Received in revised form: 25 Dec 2020; Accepted: 06 Jan 2021; Available online: 12 Jan 2021 (2021 The Author(s). Published by The Shillonga Publication. This is an open access article under the CC BY license (https://creativecommons.org/licenses/by/4.0/).

\begin{abstract}
The study was conducted in Adamawa State, Nigeria between June to November, 2019. The objective of the study was to investigate attributes which rice consumers consider when purchasing a particular type of rice. Specifically, it identifies attributes which local and imported rice consumers consider when choosing a particular rice type and examine the level of significant of these attributes in influencing choice of rice consumed in the area. The population of the study involved all the households in Adamawa State. However, the research used a sample size of 128 House Hold Heads (HHHs) for the work. Primary data was generated from the respondents through a well-structured questionnaire; however, only 120 questionnaires were retrieved and successfully used to accomplish the objective of the study. Logit regression and ordinary least square models were used to analyzed the data. The results revealed that consumers consider price of rice, swelling capacity, odor, suitability of recipe, cooking duration, taste, shape, and cleanness of a particular rice grain as an attribute before choosing a rice type as this was explained by pseudo $R^{2} 0.928$ obtained from the logit model. The study concludes that, rice attributes such as swelling capacity, suitability of recipe, cleanliness, grain shape, cooking duration and aroma as well as taste significantly had effects in deciding type of rice to consume by rice consumers in Adamawa State as at the period of study. The study recommends that, any rice to be marketed in the area must be clean and free from unpleasant odor, have good shape, good swelling capacity, taste and suitable for preparation of different recipe. This can be achieved through improvement in research and use of modern processing technologies for both production and processing of rice.
\end{abstract}

Keywords-Logit, Regression, Local, Imported, Rice, Consumers, Attributes.

\section{INTRODUCTION}

Rice is globally utilized in one form or the other (Isa et al., 2013). It is also considered as one of the food items in Nigeria whose consumption does not have cultural, religious, ethnic or geographical boundary (Opeyemi, et al., 2015).

The main concern is the rate at which rice consumption is increasing at an alarming rate. Central Bank of Nigeria (CBN, 2006), reported that, the country spends over N365 Billion yearly to import rice, indicating an average of $\mathrm{N} 1$ Billion daily (CBN, 2006), a situation which perhaps forced the Federal Government of Nigeria (FGN) to look inward toward encouraging domestic production in order to minimize rice importation and improve the food security situation in Nigeria. Nevertheless, increasing domestic output without corresponding domestic demand of rice is envisaged as a problem that needs to be addressed. Consequently, it has been well speculated that domestic production of good rice might increase availability and make it relatively affordable than the imported rice whose price is at the moment higher. Therefore, achieving both quantity and quality improvement may lead to higher incomes for farmers and investors, might create more livelihood, generate employment along the value chain, reduce poverty and guaranteed food security should be given immediate attention ( Lancorn, et. al., 2003).

Rice consumption in Nigeria has improved because it has become part of the main diet in every Nigerian home due to it's the preparation convenience and suitability for many dishes. What remains is understanding rice attributes 
which consumers consider in selecting a particular type of rice to consume?

In an effort geared toward achieving this, literature reviewed such as Ogundele et. al. (2014), reported that a range of diverse socio- cultural factors are underlining the consumption pattern and consumers preference for rice in Nigeria. They asserted that, these factors vary across the various geo- political zones in the country. Similarly, same report contained that, physical and organoleptic characteristics of rice play significant role in determining the different types of menu that can be prepared from rice. Bamidele et al. (2010), for instance, referred to rice as an important annual crop in Nigeria and a major staples, that can supply a nation's population with the nationally, required food security minimum of 2,400 calories per person per day. They further reported that an individual consumer has a set of preferences and attached values toward a particular rice (either a local or imported) which might depend upon income, education, tastes, price and other factors.

The foregoing has raised the interest of the researchers to embark on this study with the hope of evaluating the various attributes which rice consumers considered when purchasing rice because such information will be valuable in determining the choice of either local or imported rice by consumers in the area and it is necessary not only for the purpose of rice quality improvements but also for strategic planning of rice sector in Adamawa state in particular and Nigeria at large.

This study was set out to provide answer to the following questions;

What are the attributes which rice consumers consider in purchasing/consuming a particular type of rice in the study area? How significant /relevant are these attributes in choosing rice (decision making) in the study area.

\section{Objective}

The broad objective of this research was to investigate attributes which local and imported rice consumers in the area consider when choosing a particular type of rice. Specific objectives were to: identify attributes which local and imported rice consumers consider when choosing/selecting a particular rice type and to examine the level of significant of these attributes in influencing choice/decision of rice consumed in the area.

\section{MATERIALS AND METHOD}

\section{The Study Area}

Adamawa State located in the North- Eastern part of Nigeria latitude $7^{\circ}$ and $11^{\circ} \mathrm{N}$ and Longitude $11^{\circ}$ and $14^{\circ} \mathrm{E}$. It shares boundary with Taraba State in the south and west,
Gombe State in its North-west and Borno State to the North. The State has an international boundary with the Cameroon Republic along its eastern side. It has a land area of about $38,741 \mathrm{~km}^{2}$ (Adebayo, 1999). The State is divided into 21 Local Government areas. Adamawa State has a tropical wet and dry climate. Dry season lasts for a minimum of five months (November-March) while the wet season spans April to October (Adebayo, 1997).

The State is naturally divided into two ecological zones; the guinea and Sudan savannah zones. In general, the distribution of vegetation reflects the combined control of rainfall, topography and to a lesser extent, that of soils. Agriculture is the mainstay of about $80 \%$ of the inhabitants of the State. The ecological condition of the State permits cultivation of root crops, cereals and rearing of livestock in large numbers.

Maximum temperature mays reach as high as $40^{\circ} \mathrm{C}$ especially between March and April with a minimum temperature as low as $18^{\circ} \mathrm{C}$ between December and January. This temperature range is good for rice enterprise especially during grain formation and during drying after parboiling among small scale rice millers. The relative humidity between January and March ranges from 20-30\% and reached a peak of $80 \%$ in August and September (Adebayo, 1997). The mean annual rainfall is about 1000 $\mathrm{mm}$, which allow the cultivation of rice and other crop such as ground nut, guinea corn, cowpea and vegetable of different kinds (Adebayo, 1997).

\section{Sampling Techniques}

Multi stage, purposive and simple random sampling techniques were used for the study. The first stage involved consideration of the 4 Agricultural zones demarcated by Adamawa State Agricultural Development Project (ADP) Namely, Zone I, II. 111 and1V respectively. The second stage involved purposive selection of 2 Local Government Areas LGAs from each zone making a total of 8 LGAs.

The third stage involved purposive selection of one Urban/ Peri -Urban settlement and one rural settlement from each LGA; this gives a total of 16 settlements in the state.

The fourth stage involved collection of list of households in each of the ward (settlement) from the districts head office which serve as the sampling frame.

The last stage involved simple random selection of 8 households' heads from the 16 wards from the list generated which served as the sample size which gave a total of 128 respondents for the study. It should be noted, that the population of the study supposed to be all the household hesads in the study area, however this will be too large and cumbersome to handle. 
Table 1: Showing sampling distribution of respondents according to zones, local government areas and wards

Zones Local Government Areas Wards Households Sample HHHs

\begin{tabular}{lllrl} 
Zone I & Mubi - North & Yelwa & 419 & 8 \\
& & Mayo - bani & 97 & 8 \\
\multirow{2}{*}{ Zone II } & \multirow{2}{*}{ Mubi - South } & Nassarawo & 274 & 8 \\
& & Mujjara & 142 & 8 \\
& \multirow{2}{*}{ Song } & Gombi -North & 149 & 8 \\
\multirow{2}{*}{ Zone III } & Yola- south & Garkida & 55 & 8 \\
& & Song Gari & 240 & 8 \\
& \multirow{2}{*}{ Fufore } & Zumo & 106 & 8 \\
& & Adarawo & 188 & 8 \\
Zone IV & Numan & Ngurore & 336 & 8 \\
& & Fufore & 562 & 8 \\
& \multirow{2}{*}{ Lamurde } & Ribadu & 119 & 8 \\
& & Numan & 319 & 8 \\
& \multirow{2}{*}{ Total } & Imburu & 68 & 8 \\
\hline
\end{tabular}

Source: Field survey, 2019.

\section{Data Collection}

Data for the study was generated from primary source. Primary data was collected from rice consumers identified at the households levels through the use of structured questionnaire administered to Households Heads. Information captured was on attributes which consumers consider when purchasing rice.

\section{Data Analyses}

Data collected were subjected to inferential analyses. The inferential statistics is the multiple logit regression.

\section{Logit Regression}

The measure of these values in this model for particular rice is in terms of the real opportunity cost to the consumer who purchases and consumes the goods than the opportunity cost of those purchase forgone goods which the consumer could have bought instead. The level of satisfaction that consumer obtains from consuming local or imported rice depends on consumer preference.

Logit regression is one of the binary choice model in which the dependent variable takes a value of 1 or 0 . The logit model analyzed qualitative data reflecting a choice between two alternatives. The logit model ensured prediction of probability between two alternatives. The Logit regression model for attributes which consumers consider while purchasing rice is presented below:

$Y=a_{0}+a_{1} X_{1}+a_{2} X_{2}+a_{3} X_{3}+a_{4} X_{4}+a_{5} X_{5}+a_{6} X_{6}+a_{7} X_{7}+$ $\mathrm{a}_{8} \mathrm{X}_{8}+\mathrm{a}_{9} \mathrm{X}_{9}+\mathrm{u}_{\mathrm{i}}$

Where;

$\mathrm{Y} \quad=$ Rice consumption (Logit) with1 for Imported and 0 for Local

$\mathrm{X}_{1}$ to $\mathrm{X}_{9}$ are characters desired by consumers such as taste, cleanliness, color, grain shape, swelling capacity, price, color and suitability to rice and continental recipe as presented below;

$\mathrm{X}_{1} \quad=$ character of price desired for local and imported rice

$\mathrm{X}_{2}=$ character of swelling capacity desired for local and imported rice.

$\mathrm{X}_{3} \quad=$ character of taste desired for local and imported rice. 
$\mathrm{X}_{4}=$ character of cleanliness desired for local and imported rice.

$\mathrm{X}_{5}=$ character of cooking duration desired for local and imported rice.

$\mathrm{X}_{6}=$ character of color desired for local and imported rice.

$\mathrm{X}_{7}=$ character of aroma/odor desired for local and imported rice.
$\mathrm{X}_{8} \quad=$ character of grain shape desired for local and imported rice.

$\mathrm{X}_{9}=$ character of suitability of recipe desired for local and imported rice.

$\mathrm{p} \quad=$ probability of success

$1-\mathrm{p} \quad=$ probability of failure

\section{RESULTS AND DISCUSSION}

\section{Logit Model}

Table.2: Logistic regression result of rice attributes which rice consumers consider in choosing between local and imported rice in the study area

\begin{tabular}{|c|c|c|c|c|c|c|}
\hline $\mathbf{R c}$ & Coeff. & Std.Err. & $\mathbf{Z}$ & $\mathbf{P}>|\mathbf{Z}|$ & $95 \%$ Conf & Interval \\
\hline $\mathrm{X}_{1}$ & -1.310979 & .655863 & -7.92 & 0.000 & -1.635522 & -.9864362 \\
\hline $\mathrm{X}_{2}$ & .0393739 & .0212781 & 1.85 & 0.064 & -.0023304 & .0810782 \\
\hline $\mathrm{X}_{3}$ & 6407777 & .2363652 & 2.71 & 0.007 & 1.104045 & .1775104 \\
\hline $\mathrm{X}_{4}$ & 501 & .2276488 & 3.23 & 0.001 & .2889 & 1.181334 \\
\hline $\mathrm{X}_{5}$ & .6890984 & .3335912 & 2.07 & 0.039 & .0352718 & 1,3342925 \\
\hline $\mathrm{X}_{6}$ & .5958804 & .3565452 & 1.67 & 0.095 & -.1029354 & 1.294696 \\
\hline $\mathrm{X}_{7}$ & .2741774 & .5843263 & 0.47 & 0.639 & -.8710811 & 1.419436 \\
\hline $\mathrm{X}_{8}$ & .5667235 & .3225025 & 1.76 & 0.079 & -.0653697 & 1.198817 \\
\hline $\mathrm{X}_{9}$ & .6943806 & .3334412 & 2.08 & 0.037 & .0408478 & 1.347913 \\
\hline & 1.155869 & 1.017463 & & & .8383212 & 3.150059 \\
\hline
\end{tabular}

\section{Source: Author's computation using SPSS, 2019}

*(10 variables, 121 observations pasted into data editor)

$\operatorname{logit} r c \mathrm{x}_{1} \mathrm{x}_{2} \mathrm{x}_{3} \mathrm{x}_{4} \mathrm{x}_{5} \mathrm{x}_{6} \mathrm{x}_{7} \mathrm{x}_{8} \mathrm{x}_{9}$

Iteration 0: $\log$ likelihood $=-70.580253$

Iteration 1: $\log$ likelihood $=-68.743451$

Iteration 2: $\log$ likelihood $=-68.728003$

Iteration 3: $\log$ likelihood $=-68.728002$

Logistic regression Number of obs $=120$

$$
\begin{aligned}
\operatorname{LRchi}^{2}(9) & =3.70 \\
\text { Prob }>\text { chi } & =0.0262 \\
\text { Log likelihood } & =-68.728002 \\
\text { Pseudo } \mathrm{R}^{2} & =0.9298
\end{aligned}
$$

The logit result is presented in table 2 above. It revealed that, all the independent variables have positive effect on the dependent variable except for $\mathrm{X}_{1}$ which have negative effect on the dependent variable. Comprehensively, the result reveals that $X_{1}$ which stands for the price of rice is negative and had significant effect on rice consumption in Adamawa state evidenced by the value of Z-statistics at
$95 \%$ confidence interval. It shows that it is 1.31 times more likely for consumers to shy away from rice consumption as the price of rice increases by a unit and vice versa.

Also, the logit result found that $\mathrm{X}_{2}$ representing character of swelling capacity desired for local and imported rice has positive effect on rice consumption. It quantitatively shows that, the logit will go up by about 0.039 times should rice 
swelling capacity attribute of rice increases by a unit and vice versa. The logit result also found that it is 0.64 times more likely for consumers of rice in Adamawa State to increase their sizes of rice consumption should the desired taste $\left(\mathrm{X}_{3}\right)$ for both local and imported rice increases by a unit and vice versa.

Similarly, the logit revealed that $\mathrm{X}_{4}$ representing cleanliness of rice desired is positively related to the dependent variable meaning that, it is 0.74 times more likely for consumers of rice in Adamawa State to increase their rate of rice consumption should the cleanliness of rice desired by the consumers increases by a unit and vice versa. The result further revealed that $X_{5}$ representing cooking duration of rice desired has positive effect on rice consumption. It precisely shows that, it is 0.69 times more likely for rice consumers in Adamawa State to increase their frequency of rice consumption should the cooking duration desired by consumers increase by a unit and vice versa.

Furthermore, the logit result revealed that it is 0.59 times more likely for consumers of rice in Adamawa state to increase their rice consumption level should the color $\mathrm{X}_{6}$ of rice desired by consumers increase by a unit and vice versa. The $Z$-statistics value revealed that it is not statistically significant at 5\% level of significance; however, it is significant at $10 \%$ level of significant. The result further found that, $X_{7}$ representing character of aroma/odor desired has positive and insignificant effect on rice consumption meaning that consumers of rice in Adamawa State do not so much pay attention to the aroma/odor of rice they consume since it is not statistically significant both at $5 \%$ and $10 \%$ level of significance owing to evidence given by the probability of Z-statistics. $\mathrm{X}_{8}$ which stands for grain shape desired by consumers have positive effect on rice consumption in Adamawa State. The logit revealed that it is 0.57 times more likely for consumers to increase their rice consumption level should the shape of the grain desired increase by a unit and vice versa. The Z-statistics result revealed that, its effect is not statistically significant at $5 \%$ level of significant but is significant at $10 \%$ level of significant. Also, $\mathrm{X}_{9}$ standing for suitability of recipe desired has positive and significant effect on rice consumption in Adamawa State. The logit showed that it is 0.69 times more likely for consumers of rice in Adamawa State to increase rice consumption level should suitability of recipe attribute of rice grain whether local or imported be increased by a unit and vice versa.

The Pseudo $\mathrm{R}^{2}$ which measure the degree of variation in the dependent variable explained by the independent variables put together has a value of 0.93 meaning that about $93 \%$ of rice consumption in Adamawa
Sate is influenced by price of rice, swelling capacity, aroma/odor, suitability of recipe, cooking duration, taste, shape of rice grains, color and cleanliness. The LR statistic result which measure the statistical significance of the effect of all the independent variables on the dependent variable revealed that the overall effect is statistically significant in determining changes in the dependent variable which translate to rice consumption level.

\section{CONCLUSION}

The study concludes that, rice attributes such as swelling capacity, suitability of recipe, cleanliness, grain shape, cooking duration and aroma as well as taste among others significantly had effects in deciding type of rice to buy/consume by rice consumers in Adamawa State as at the period of study which covered. Therefore, producers and marketers should pay attention to these attributes.

\section{RECOMMENDATIONS}

Based on the findings of the study, the researchers recommended the followings:

For any rice to be marketed in the area, it should to be clean, free from unpleasant odor have good shape, good swelling capacity, taste and suitable for preparation of different recipe for it to receive well patronize. In addition to possessing all these attributes, it needs to be relatively cheaper to command good demand. These could be achieved through:

Improvement in research and use of modern technologies for both production and processing of rice will go a long way in increasing quality and therefore should be promoted.

Government and non-governmental organizations should support rice millers to acquire milling skills and facilities. This can be achieved through sensitization and effective capacity building and introduction of affordable credit facilities or grant to the actors.

Attractive packaging technologies should be encouraged to arouse interest on domestic rice. This can be achieved through technical and financial support.

Government policies should be consistent and geared towards encouraging sufficient production and processing of domestic rice in order to compete with other imported rice.

Improving domestic production and consumption will increase livelihood potentials along the rice chain, improve revenue to government through tax collection from rice marketing. 


\section{REFERENCES}

[1] Adebayo. A. A. (1997). The agroclimatology of rice production in Adamawa State Nigeria unpublished $\mathrm{PhD}$. Thesis Department of Geography Federal University of Technology Yola. International Journal of community development and development and management study.

[2] Adebayo, A. A. and Tukur, A. L. (1999). Climate I: Sunshine, Temperature, Evaporation and Relative humidity in Adamawa State in Maps. Paraclette Publishers, Yola. pp 20-22

[3] Bamidele, F. S. A., Bayomi, O. O. and Ester, O. A. (2010) Economic analysis of rice consumption Pattern in Nigeria. Journal of agricultural science and technology.12:-1-11.e production in Nigeria: A survey project report - The Nigeria 49 Rice Economy in a competitive world. Constraints, opportunities and strategies choices. Abidjan WARDA.

[4] Central Bank of Nigeria (CBN, 2006). Statistical Bulletin 2006.

[5] Opeyemi, G., Adedeji2, S. O., Komolafe3*, S. E., Arotiba1, K. and Ifabiyi 3, J. O (2015) Analysis of Consumers' Preference in Patronizing Locally Produced And Imported Rice In Niger State, Nigeria. Nigerian Journal of Agriculture, Food and Environment. 11(3):3843.

[6] Ogundele, O. (2014). Factors influencing Consumers preference for local rice in Nigeria. African Journal of marketing management Vol. 6. (4) pp 49 - 55 DOI: 10.5897/AJMM 2011.048

[7] Lançon F., Erenstein O., Akande S. O., Titilola S. O., Akpokodje G. and Ogundele O. O. (2003), Imported Rice Retailing and Purchasing in Nigeria: A Survey. In Erensten O. and Lancon O. (2003) eds. The Nigerian Rice Economy in a Competitive World: Constraints, Opportunities and Strategic Choices. West Africa Rice Development Association (WARDA), Abidjan, Cote D' Voire. 